\title{
UPAYA MENINGKATKAN HASIL BELAJAR PKN MENGGUNAKAN MODEL ACTIVE LEARNING TIPE ROLE REVERAL QUESTION PADA SISWA KELAS X SMA MELATI BINJAI
}

\author{
Muhamad Fatra Fadriansyah ${ }^{1}$, Surya Wibawa ${ }^{2}$ \\ STKIP Budidaya Binjai
}

\begin{abstract}
ABSTRAK
Subyek penelitian ini adalah siswa-siswi kelas X SMA Swasta Melati Binjai berjumlah 36 siswa. Terdiri dari 21 siswa laki-laki dan 15 siswa perempuan. Sedangkan obyek penelitian ini adalah hasil belajar PKn menggunakan model active learning tipe role reversal question.

Jenis penelitian tindakan kelas yang digunakan dalam penelitian ini adalah kolaboratif, dalam artian peneliti terlibat dalam kegiatan yang digunakan sebagai sumber data penelitian.Berdasarkan hasil penelitian keseluruhan siswa baru ada 16 siswa atau $44 \%$ dari jumlah siswa yang memperoleh nilai $\geq 70$. sedangkan 20 siswa atau $56 \%$ dari jumlah siswa memperoleh nilai $<70$. nilai rata-rata siswa pada pra tindakan yaitu 66,53. data tersebut menunjukkan bahwa $75 \%$ dari jumlah siswa yang belum memperoleh nilai $\geq 70$, hal tersebut masih jauh dari target yang diharapkan.

Dari hasil evaluasi yang dilakukan, nilai rata-rata yang diperoleh dalam hasil evaluasi pada siklus I yaitu 75,27 . Siswa yang memperoleh nilai $\geq 70$ sebanyak 25 siswa atau $69 \%$ dari jumlah siswa, sedangkan 11 siswa atau $31 \%$ dari jumlah siswa memperoleh nilai $<70$. Hal tersebut menunjukkan bahwa penelitian tindakan kelas pada siklus I belum mencapai kriteria keberhasilan yang ditentukan, karena $\geq 75 \%$ dari jumlah siswa belum memperoleh nilai $\geq 70$. Untuk itu penelitian dilanjutkan ke siklus II. Hasil belajar siswa setelah dilakukan perbaikan tindakan pada siklus II mengalami kenaikan secara signifikan dari pra tindakan, siklus I dan sikus II. Nilai rata-rata hasil belajar siswa naik 8,75\% dari kondisi awal 66,53 menjadi 75,27 pada siklus I, dan meningkat lagi $10,97 \%$ menjadi 86,2 .
\end{abstract}

Kata kunci : meningkatkan, hasil belajar pkn, active learning, role reveral question. 


\section{PENDAHULUAN}

\section{a) Latar Belakang}

Pendidikan merupakan pengalaman belajar yang berlangsung dalam lingkungan dan diperoleh sepanjang hidup. Pendidikan dilakukan oleh keluarga, masyarakat dan pemerintah.

Pendidikan formal merupakan satuan pendidikan di Indonesia. Menurut UndangUndang Republik Indonesia Nomor 20 Tahun 2003 pasal 1 tentang Sistem Pendidikan Nasional, diartikan bahwa sebagai kelompok layanan pendidikan pada jalur formal, nonformal dan informal ada setiap jenjang dan jenis pendidikan. Karakteristik anak usia sekolah dasar masuk berada pada tahap operasional konkret, dimana aktivitas mental yang difokuskan pada obyek dan peristiwa yang nyata. kurang mampu berfikir abstrak. Jika dilihat dari pemikiran dan karakteristik anak usia SMA, maka dalam pelaksanaan pembelajaran PKn guru dapat merencanakan kegiatan yang mengandung unsur keterlibatan siswa secara langsung.

Kenyataannya dalam proses pembelajaran PKn di SMA siswa belum sepenuhnya terlibat secara langsung, seperti halnya yang terjadi pada Kelas X SMA Swasta Melati Binjai. Kegiatan pembelajaran masih di dominasi oleh aktivitas guru yaitu dengan pengunaan metode ceramah saat menerangkan materi pelajaran. Berdasarkan observasi yang dilakukan pada saat kegiatan pembelajaran PKn berlangsung, siswa yang tidak sepenuhnya memperhatikan penjelasan guru, dikarenakan bosan dengan aktivitas mendengarkan, sehingga pembelajaran PKn dirasa kurang menyenangkan bagi siswa.

Seperti yang sudah dipaparkan sebelumnya kegiatan guru dalam menyampaikan pembelajaran PKn di Kelas X SMA Swasta Melati Binjai masih didominasi dengan kegiatan ceramah, menghafal materi dan pemberian tugas.

Berdasarkan uraian di atas, peneliti terdorong untuk mengadakan penelitian dengan judul "Upaya Meningkatkan Hasil Belajar PKn Menggunakan Model Active Learning Tipe Role Reversal Question Pada Siswa Kelas X SMA Swasta Melati Binjai".

\section{b) Identifikasi Masalah}

Berdasarkan latar belakang yang telah dikemukakan di atas dapat diidentifikasi masalah sebagai berikut:

1. Kegiatan pembelajaran monoton, guru selalu menggunakan metode ceramah.

2. Siswa kurang aktif dalam pembelajaran, ditandai dengan kegiatan pembelajaran didominasi oleh guru.

3. Motivasi siswa dalam mengikuti pembelajaran rendah, terlihat saat mengikuti proses pembelajaran siswa membuat gaduh dan tidak mengerjakan tugas dengan sungguh-sungguh.

4. Nilai rata-rata PKn masih rendah, untuk itu perlu dilakukan peningkatan hasil belajar

5. Guru belum menerapkan model active learning tipe role reversal question dalam kegiatan pembelajaran PKn.

\section{c) Batasan Masalah}

Berdasarkan identifikasi masalah di atas, peneliti membatasi masalah pada upaya meningkatkan hasil belajar PKn menggunakan Model Active Learning Tipe Role Reversal Question pada siswa Kelas X SMA Swasta Melati Binjai.

\section{d) Rumusan Masalah}

Berdasarkan batasan masalah di atas, maka rumusan masalah dalam penelitian ini adalah bagaimana meningkatkan hasil belajar PKn dengan menggunakan Model Active Learning Tipe Role Reversal Question pada siswa Kelas X SMA Swasta Melati Binjai?

\section{e) Tujuan Penelitian}

Berdasarkan rumusan masalah di atas, maka tujuan penelitian ini adalah untuk mendeskripsikan peningkatan hasil belajar PKn siswa Kelas X SMA Swasta Melati Binjai dengan menggunakan Model Active Learning Tipe Role Reversal Question.

\section{1) Pengertian Belajar}

Belajar adalah suatu proses usaha yang dilakukan untuk memperoleh perubahan tingkah laku dari interaksi dengan lingkungannya yang diperoleh hasil pengalaman. Belajar dapat dipahami sebagai tahapan perubahan pengalaman dan interaksi yang diperoleh dari lingkungan yang melibatkan proses kognitif. Perubahan tingkah 
laku dalam belajar diperlukan waktu dan proses yang bertahap. Selain itu interaksi lingkungan juga berpengaruh, karena dalam belajar diperoleh pengalaman melalui interaksi lingkungan.

\section{2) Ciri Karakteristik Belajar} berikut:

Karakteristik pembelajaran ialah sebagai

a. Belajar adalah menguasai atau memperoleh.

b. Belajar adalah mengingat-ingat informasi atau keterampilan.

c. Proses mengingat-ingat melihat sistem penyimpanan, memori, dan organisasi kognitif.

d. Belajar melibatkan perhatian aktif sadar dan bertindak menurut peristiwa-peristiwa di luar serta di dalam organisasi.

e. Belajar bersifat permanen, tetapi tunduk pada lupa.

f. Belajar melibatkan berbagai bentuk latihan, mungkin latihan yang ditopang dengan imbalan dan hukum.

g. Belajar adalah suatu perubahan dalam perilaku. Berdasarkan pendapat tersebut diketahui bahwa belajar merupakan kegiatan yang bertujuan untuk menguasai atau memperoleh suatu pengetahuan. Dalam belajar dibutuhkan keterlibatan secara langsung. Keterlibatan tersebut dapat berupa mengingat-ingat suatu informasi atau dengan melakukan latihan. Dengan demikian dapat terjadi perubahan tingkah laku sesuai dengan yang diharapkan.

Merupakan perubahan perilaku yang bersifat relative permanent dan bersifat potensial. Dikatakan relative permanent karena saat belajar terjadi perubahan perilaku dalam kurun waktu tertentu. Perubahan perilaku yang terjadi hanya bersifat sementara tidak sampai pada akhir khayat. Kemudian dikatakan perubahan perilaku potensial dikarenakan perubahan perilaku yang terjadi tidak langsung dapat dilihat saat itu juga atau tidak terlihat langsung pada proses pembelajaran. Perubahan perilaku ini dapat dilihat saat pembelajaran selesai.

\section{3) Pengertian Hasil Belajar}

Tujuan akhir dilaksanakannya kegiatan pembelajaran yaitu untuk memperoleh hasil belajar. Hasil belajar diperoleh jika terjadi perubahan tingkah laku, dari tidak tahu menjadi tahu dan dari tidak mengerti menjadi mengerti.
Perubahan tersebut dapat diartikan terjadinya peningkatan dan perkembangan lebih baik dari sebelumnya. Hasil belajar merupakan pola perbuatan, nilai-nilai, pengertian-pengertian, sikap-sikap, apresiasi dan keterampilan. Dengan demikian hasil belajar tidak hanya berdasarkan nilai atau skor yang diperoleh dalam kegiatan pembelajaran.

Hasil belajar dapat berupa informasi verbal, keterampilan intelektual, strategi kognitif, keterampilan motorik, dan sikap. Informasi verbal merupakan kemampuan dalam mengungkapkan pengetahuan baik dam bentuk bahasa, lisan maupun tertulis.

\section{Pengertian Pendidikan Kewarganegaraan}

Pendidikan Kewarganegaraan merupakan program pendidikan yang menekankan pada pembentukan warganegara agar dapat melaksanakan hak dan kewajiban. Sebagaimana disebutkan dalam Permendiknas Nomor 22 Tahun 2006 yaitu:

"Mata pelajaran PKn merupakan mapel yang memfokuskan pada pembentukan warganegara yang memahami dan mampu melaksanakan hak-hak dan kewajibannya untuk menjadi warga Negara Indonesia yang cerdas, terampil, berkarakter yang diamanatkan oleh Pancasila dan Undang-undang 1945.

Pendidikan Kewarganegaraan merupakan pendidikan demokrasi yang bertujuan untuk mempersiapkan masyarakat berfikir kritis dan bertindak melalui dengan menanamkan kesadaran bahwa demokrasi adalah bentuk kehidupan yang menjamin hak masyarakat. Pendidikan Kewarganegaraan (civic education) ditandai oleh kegiatan yang sudah diprogramkan oleh sekolah. Kegiatan ini meliputi kegiatan pembelajaran yang dapat menumbuhkan perilaku yang baik. Pendidikan Kewarganegaraan dilakukan dengan kegiatan yang menyangkut pengalaman yang dikaitkan dengan kehidupan nyata seperti kehidupan dalam keluarga dan masyarakat.

\section{Pengertian Model Pembelajaran Aktif ( Active Learning)}

Pembelajaran aktif (active learning) merupakan suatu pembelajaran yang menekankan siswa untuk aktif dalam belajar. Kegiatan pembelajaran lebih didominasi pada 
aktivitas siswa. Kegiatan pembelajaran tidak hanya menekankan pada aktivitas mental namun juga melibatkan aktifitas fisik, sehingga suasana pembelajaran lebih nyaman dan menyenangkan. Pembelajaran aktif (active learning) merupakan pembelajaran yang memungkinkan siswa turut aktif salam proses pembelajaran, baik dalam bentuk interaksi antar siswa maupun siswa dengan guru.

Dari pendapat yang sudah dijelaskan dapat di ambil kesimpulan bahwa pembelajaran aktif (active learning) merupakan kegiatan belajar yang mengaktifkan siswa, dalam artian siswa terlibat langsung dalam pembelajaran. Pembelajaran aktif membutuhkan interaksi antara guru dengan siswa, serta melibatkan kemampuan siswa baik kognitif, afektif serta prikomotorik, yang diperoleh dari pengalaman belajar.

\section{Kerangka Konseptual}

Hasil ujian semester ganjil mata pelajaran PKn kelas X SMA Swasta Melati Binjai menunjukkan bahwa rata-rata hasil belajar siswa masih rendah. Terdapat 18 atau $50 \%$ dari jumlah siwa dari 36 siswa yang nilainya dibawah kriteria ketuntasan minimal. Sehingga terdapat 18 atau $50 \%$ dari jumlah siswa yang belum mencapai nilai ketuntasan minimal pada mata pelajaran PKn. Untuk itu perlu ada peningkatan hasil belajar PKn.

Proses pembelajaran $\mathrm{PKn}$ di kelas $\mathrm{X}$ masih menggunakan metode ceramah dan pemberian tugas. Penggunaan metode ceramah dalam pembelajaran PKn yang dilakukan guru belum mengaktifkan siswa, sehingga siswa hanya mendengarkan dan pasif dalam kegiatan belajar. Bertolak dari masalah tersebut diperlukan upaya untuk mengoptimalkan pembelajaran PKn, agar dalam menyampaikan materi guru tidak hanya menggunakan metode ceramah namun menggunakan kegiatan pembelajaran yang melibatkan siswa aktif dalam pembelajaran, agar siswa mudah untuk memahami materi pembelajaran. Alternative pembelajaran yang dapat digunakan yaitu dengan menerapkan model active learning tipe role reversal question.

Model pembelajaran aktif (active learning) merupakan model pembelajaran yang melibatkan siswa aktif dalam belajar. Dalam pembelajaran aktif (active learning) pengalaman merupakan hal yang ditekankan, sehingga siswa lebih banyak terlibat dalam belajar. Salah satu tipe model active learning yaitu role reversal question. Model ini menerapkan keaktifan siswa dalam pembelajaran, karena model active learning tipe role reversal question siswa memerankan suatu peran kemudian dilanjutkan dengan melakukan tanya jawab dengan siswa yang lain. Sehingga dalam penerapan model active learning tipe role reversal question terjadi timbal balik dari kegiatan pembelajaran yang berlangsung.

\section{Hipotesis Tindakan}

Berdasarkan kajian teori dan kerangka pikir, maka hipotesis tindakan pada penelitian tindakan kelas yaitu penggunaan model active learning

\section{METODOLOGI PENELITIAN}

\section{a. Jenis Penelitian}

Penelitian ini merupakan penelitian tindakan kelas (classroom action research). Menurut Suharsimi Arikunto dkk, penelitian tindakan kelas merupakan suatu pencermatan dari kegiatan pembelajaran berupa tindakan yang sengaja dimunculkan dan terjadi pada sebuah kelas secara bersama. Adapun tujuan penelitian ini adalah untuk meningkatkan hasil belajar PKn menggunakan model active learning tipe role reversal question kelas X SMA Swasta Melati Binjai.

Jenis penelitian tindakan kelas yang digunakan dalam penelitian ini adalah kolaboratif, dalam artian peneliti terlibat dalam kegiatan yang digunakan sebagai sumber data penelitian (Sugiono). Dalam penelitian ini dilakukan kolaborasi antara peneliti dan guru PKn Kelas X SMA Swasta Melati Binjai. Guru bertindak sebagai subyek yang melakukan tindakan sedangkan peneliti sebagai pengamat (observer).

\section{b. Lokasi dan Waktu Penelitian}

Lokasi penelitian yang digunakan dalam penelitian ini yaitu di dalam Kelas X SMA Swasta Melati Binjai. Pengambilan data pada penelitian ini dilakukan pada bulan Nopember sampai Desember 2016.

\section{c. Subjek Dan Objek Penelitian}

Subyek penelitian ini adalah siswa-siswi kelas X SMA Swasta Melati Binjai berjumlah 36 siswa. Terdiri dari 21 siswa laki-laki dan 15 siswa perempuan. Sedangkan obyek penelitian ini adalah hasil belajar PKn menggunakan model active learning tipe role reversal question. 


\section{d. Desain Penelitian}

Menurut Suharsimi Arikunto, penelitian tindakan kelas dilakukan sekurangkurangnya dalam dua siklus tindakan yang berurutan. Ada beberapa ahli yang mengemukakan model penelitian tindakan, namun secara garis besar terdapat empat tahapan yang dilalui yaitu (1) perencanaan, (2) pelaksanaan, (3) pengamatan dan (4) refleksi. Adapun model dan penjelasan untuk masing- masing tahap berikut:

\section{e. Metode Pengumpulan Data}

Metode pengumpulan data yang digunakan dalam penelitian tindakan kelas ini meliputi tes, observasi, dan dokumentasi.

\section{F. Instrumen Penelitian}

\section{Tes}

Tes disusun berdasarkan indikator yang akan dicapai. Soal tes diberikan diberikan pada akhir siklus, yang bertujuan untuk mengetahui hasil belajar PKn siswa setelah mengikuti pembelajaran dengan menggunakan model active learning tipe role reversal question. Bentuk soal yang diberikan adalah pilihan ganda (obyektif). Jumlah soal tiap siklus adalah 20 butir soal dengan opsi jawaban a,b,c dan d. Soal tes yang diberikan berisi materi PKn yang di sampaikan. Adapun kisi-kisi soal yang akan digunakan dalam

\section{f. Teknis Analisis Data}

Dalam penelitian tidakan kelas (PTK) analisis data diarahkan untuk mencari dan menemukan upaya yang dilakukan guru dalam meningkatkan hasil belajar siswa terutama pada mata pelajaran PKn dengan menuggunakan model active learning tipe role reversal question. Dengan demikian analisis data yang digunakan dalam penelitian kelas dapat menggunakan analisis kuantitatif dan kualitatif.

1. Data kuantitatif diperoleh dari hasil belajar dan aktivitas siswa. Hasil belajar diperoleh melalui tes yang dilakukan pada akhir siklus, sedangkan data aktivitas siswa diperoleh dari pengamatan dalam kegiatan pembelajaran PKn menggunakan model active learning tipe role reversal question. Rumus statistik yang digunakan untuk mengolah hasil belajar siswa menggunakan statistik sederhana yaitu menggunakan rumus mencari skor rerata kelas. Skor yang diperoleh dengan menjumlahan seluruh skor siswa dan dibagi dengan jumlah siswa. Rumus tersebut sebagai berikut.

\section{Hasil Penelitian \\ 1. Deskripsi Data Sebelum Tindakan}

Sebelum melakukan tindakan penelitian, terlebih dahulu peneliti melakukan tahap pra tindakan berupa observasi mengenai kegiatan pembelajaran PKn di Kelas X SMA Swasta Melati Binjai. Kegiatan tersebut dilakukan untuk mengetahui gambaran awal mengenai kegiatan siswa saat pembelajaran PKn disampaikan. Dari hasil observasi di ketahui bahwa kegiatan pembelajaran masih berpusat pada guru hal tersebut dibuktikan dengan kegiatan guru yang lebih dominan pada saat pembelajaran PKn.

\section{Pengamatan Siklus I}

Sesuai dengan tujuan peneliti yaitu meningkatkan hasil belajar PKn menggunakan model active learning tipe role reversal question pada siswa Kelas X SMA Swasta Melati Binjai, maka pengamatan tindakan dengan menggunakan instrument sebagai berikut.

Hasil belajar diperoleh dari tes yang dilakukan pada setiap akhir siklus. Data yang diperoleh berupa angka mengenai nilai yang diperoleh masing-masing siswa terhadap soal yang dikerjakan setelah diterapkannya model active learning tipe role reversal question dalam proses pembelajaran PKn. Soal yang diberikan dalam tes ini adalah 20 soal tipe pilihan ganda. Hasil belajar siswa pada siklus I dapat dikelompokkan berdasarkan rentang

Berdasarkan tabel diatas, tidak ada siswa yang memperoleh nilai 0-49. Siswa yang memperoleh nilai 50-59 atau pada kriteria kurang berjumlah 2 siswa. Siswa yang memperoleh nilai 60-69 atau pada kriteria cukup diperoleh 9 siswa. Siswa yang memperoleh nilai 70-79 atau pada kriteria baik berjumlah 6 siswa. Sedangkan nilai 85-100 atau pada kriteria sangat baik berjumlah 19 siswa. Nilai rata-rata siswa pada siklus I yaitu 75,27.

\section{d. Refleksi}


Refleksi dilakukan berdasarkan hasil belajar PKn dengan menggunakan model active learning tipe role reversal question pada siswa kelas X SMA Swasta Melati Binjai. Hal ini dilakukan untuk mengetahui hasil belajar yang diperoleh siswa menggunakan model active learning tipe role reversal question. Pelaksanaan refleksi dilakukan dengan diskusi antara peneliti dan guru kelas yang bersangkutan.

Dari hasil evaluasi yang dilakukan, nilai rata-rata yang diperoleh dalam hasil evaluasi pada siklus I yaitu 75,27. Siswa yang memperoleh nilai $\geq 70$ sebanyak 25 siswa atau $69 \%$ dari jumlah siswa, sedangkan 11 siswa atau $31 \%$ dari jumlah siswa memperoleh nilai $<70$. Hal tersebut menunjukkan bahwa penelitian tindakan kelas pada siklus I belum mencapai kriteria keberhasilan yang ditentukan, karena $\geq 75 \%$ dari jumlah siswa belum memperoleh nilai $\geq 70$. Untuk itu penelitian dilanjutkan ke siklus II guna melihat peningkatan hasil belajar siswa. Selain hasil evaluasi belajar siswa, data lain yang didapatkan melalui observasi yang dilakukan dari penelitian ini ialah mengenai aktivitas dan dan siswa dalam kegiatan pembelajaran PKn menggunakan model active learning tipe role reversal question. Berdasarkan hasil penelitian pada siklus I, secara keseluruhan pelaksanaan pembelajaran $\mathrm{PKn}$ menggunakan model active learning tipe role reversal question sudah berjalan dengan baik. Namun dalam pertemuan pertama pada siklus I guru menjelaskan kegiatan pembelajaran saat siswa sedang melakukan diskusi secara berkelompok. Hal tersebut yang menjadikan kendala, karena guru seharusnya menjelaskan kegiatan pembelajaran sebelum melakukan diskusi.

Proses belajar siswa menjadi terganggu, karena disaat sedang berdiskusi, guru menjelaskan rangkaian kegiatan pembelajaran secara singkat. Beberapa siswa mendengarkan penjelasan guru namun yang lain fokus dengan diskusi. Setelah kegiatan diskusi selesai guru menugaskan siswa untuk membuat pertanyaan individu. Terdapat siswa yang masih bingung mengenai tugas tersebut, sehingga guru menjelaskan kembali mengenai pertanyaan yang dibuat. Pada kegiatan tanya jawab dengan bertukar peran, guru menjelaskan aturan pertukaran peran. Hal tersebut dilakukan karena siswa belum mengerti aturan yang diberlakukan saat kegiatan tanya jawab dengan bertukar peran. Setelah siswa mengerti, dilakukan kegiatan tanya jawab dengan bertukar peran.

Upaya yang perlu dilakukan sebagai perbaikan tindakan agar guru tidak melakukan penjelasan kegiatan pembelajaran secara berulang-ulang pada siklus II yaitu dengan menjelaskan kegiatan pembelajaran sebelum kegiatan diskusi. Siswa diberikan pemahaman terlebih dahulu mengenai kegiatan pembelajaran. Setelah siswa paham, kegiatan pembelajaran dilaksanakan sesuai dengan rencana yang dibuat. Guru diharapkan untuk membimbing dan mengarahkan siswa agar kegiatan pembelajaran berjalan dengan baik.

\section{Pengamatan Siklus II}

Hasil belajar diperoleh dari tes yang dilakukan pada setiap akhir siklus. Data yang diperoleh berupa angka mengenai nilai yang diperoleh masing-masing siswa terhadap soal yang dikerjakan setelah diterapkannya model active learning tipe role reversal question dalam proses pembelajaran PKn. Hasil belajar siswa pada siklus II dapat dikelompokkan berdasarkan rentang nilainya.

Untuk lebih jelasnya dapat dilihat pada lampiran 3 halaman 142. Berdasarkan tabel diatas diketahui bahwa sebanyak 35 siswa atau $97 \%$ dari jumlah siswa yang memperoleh nilai $\geq 70$. Sedangkan 1 siswa atau 3\% dari jumlah siswa memperoleh nilai <70. Pada siklus II diperoleh nilai rata-rata sebesar 86,25. Berdasarkan data tersebut dapat diperoleh capaian hasil belajar siswa pada siklus II yang dapat dilihat pada tabel berikut./

Refleksi dilakukan berdasarkan hasil belajar PKn dengan menggunakan model active learning tipe role reversal question pada siswa Kelas X SMA Swasta Melati Binjai. Hal ini dilakukan untuk mengetahui hasil belajar yang diperoleh siswa menggunakan model active learning tipe role reversal question.

Hasil belajar PKn selama proses pembelajaran pada siklus II sebanyak 35 siswa yang memenuhi kriteria keberhasilan tindakan yang telah ditentukan. Hasil belajar siswa yang tergolong belum mencapai nilai $\geq 70$ pada siklus I sudah meningkat sehingga kriteria keberhasilan yang ditentukan tercapai pada siklus II. Jika pada siklus I siswa yang memenuhi kriteria keberhasilan tindakan berjumlah 25 atau $69 \%$ dari jumlah siswa maka pada siklus II meningkat $28 \%$ menjadi 35 atau 97\% dari jumlah siswa. 
Pada siklus II kegiatan siswa lebih terarah. Guru sudah melaksanakan kegiataan pembelajaran sesuai dengan rencana yang dibuat sehingga jalannya pembelajaran dengan baik. Guru memberi dorongan agar siswa percaya diri terutama dalam menjawab pertanyaan. Guru juga membimbing siswa untuk menjawab pertanyaan dengan benar. Selain itu guru menekankan bahwa selama siswa diberi kesempatan untuk menjawab gunakan kesempatan tersebut dengan sebaikbaiknya, jika jawaban kurang tepat maka guru memberi penguatan memberi penjelasan mengenai jawaban yang benar dan tetap mengapresiasi siswa yang sudah berani menjawab pertanyaan.

\section{B. Pembahasan}

Pada tahap pra tindakan yang diberikan oleh 36 siswa, diperoleh nilai rata- rata hasil belajar sebesar 66,53. Jumlah siswa yang memperoleh nilai $\geq 70$ berjumlah 16 siswa atau $44 \%$, sedangkan 20 siswa atau 56\% dari jumlah siswa memperoleh nilai $<70$. Hal tersebut menunjukkan bahwa hasil belajar siswa untuk mata pelajaran PKn di SMA Swasta Melati Binjai masih cukup jauh dari target yang diharapkan. Untuk itu peneliti merasa perlu melakukan penelitian tindakan guna meningkatkan hasil belajar yang belum sesuai dengan harapan. Melihat hal tersebut, peneliti berusaha meningkatkan hasil belajar PKn pada siswa kelas X SMA Swasta Melati Binjai dengan menggunakan model active learning tipe role reversal question.

Pada siklus I terjadi peningkatan rata-rata hasil belajar sebesar $8,75 \%$ yaitu dari 66,53 pada kondisi awal menjadi 75,27. Jumlah siswa yang memperoleh nilai $\geq 70$ mengalami peningkatan sebesar $25 \%$ dari kondisi awal $44 \%$ menjadi $69 \%$. Hal ini membuktikan bahwa tindakan pada siklus I memiliki pengaruh terhadap hasil belajar siswa pada mata pelajaran PKn.

Pada siklus II pertemuan kedua terdapat kegiatan tambahan setelah melakukan diskusi kelompok yaitu mensimulasikan pemilihan ketua kelas. Setelah berdiskusi mengenai caracara pemilihan ketua kelas, siswa dibimbing guru untuk belajar mensimulasikan pemilihan ketua kelas dengan pemungutan suara secara langsung. Terdapat 2 calon ketua kelas, kemudian siswa melakukan pemungutan suara dengan mengacungkan jari, dengan ketentuan yang memperoleh suara terbanyak menjadi ketua. Kegiatan selanjutnya siswa ditugaskan untuk membuat pertanyaan dan melakukan pertukaran peran untuk tanya jawab. Pada kegiatan perputaran peran antusias siswa untuk mendapatkan reward sangat tinggi, setiap ada pertanyaan baik dari guru maupun siswa, hampir semua siswa mengacungkan jari untuk menjawab. Saat siswa menjadi guru siswa memberi pertanyaan namun guru tidak langsung menjawab, hal tersebut dilakukan untuk memberikan kesempatan bagi siswa lain menjawab pertanyaan, dan guru memberikan penguatan atas jawaban siswa. Seperti Siklus I, pada akhir pertemuan kedua Siklus II dilakukan evaluasi untuk melihat peningkatan hasil belajar siswa.

Hasil belajar siswa setelah dilakukan perbaikan tindakan pada siklus II mengalami kenaikan secara signifikan dari pra tindakan, siklus I dan sikus II. Nilai rata-rata hasil belajar siswa naik $8,75 \%$ dari kondisi awal 66,53 menjadi 75,27 pada siklus I, dan meningkat lagi $10,97 \%$ menjadi 86,25 pada siklus II.

Siswa yang memperoleh nilai $\geq 70$ meningkat $25 \%$ dari kondisi awal $44 \%$ menjadi $69 \%$ pada siklus I, dan meningkat lagi $28 \%$ menjadi $97 \%$ pada siklus II. Dengan demikian siklus II sudah mencapai kriteria keberhasilan tindakan yang ditentukan yaitu $75 \%$ dari jumlah siswa memperoleh nilai $\geq 70$, sehingga penelitian berhenti pada siklus II.

Peningkatan juga terjadi pada aktivitas siswa dalam penerapan model active learning tipe role reversal question pada mata pelajaran $\mathrm{PKn}$. Aktivitas kerjasama pada siklus I $76 \%$ meningkat $19 \%$ menjadi $95 \%$ pada siklus II.

Aktivitas tanggung jawab pada siklus I $75 \%$ meningkat $22 \%$ menjadi $97 \%$ pada siklus II. Aktivitas bertanya pada siklus I $85 \%$ meningkat $8 \%$ menjadi $93 \%$ pada siklus II. Aktivitas menjawab pertanyaan pada siklus I 58\% meningkat $27 \%$ menjadi $85 \%$ pada siklus II.

Peningkatan yang terjadi pada siklus I dan sikus II tidak terlepas dari kegiatan guru yang telah menerapkan model active learning tipe role reversal question pada mata pelajaran PKn sesuai dengan karakteristik model active learning menurut Moh. Sholeh Hamid (2011: 49-50) yaitu kegiatan pembelajaran menekankan pada aktivitas belajar siswa dan pembelajaran tidak 
hanya pasif siswa mendengarkan penjelasan guru. Kegiatan pembelajaran lebih didominasi pada aktivitas siswa dalam memperoleh pengalaman belajar secara langsung dengan bimbingan guru. Hal ini sesuai dengan pendapat R. Ibrahim dan Nana Syaodih bahwa dalam pembelajaran guru hendaknya merencanakan pengajaran yang menuntut aktivitas siswa. Dengan menerapkan model active learning tipe role reversal question siswa tidak hanya aktif dalam pembelajaran, namun juga dibina untuk memiliki sikap cerdas, trampil, berfikir kritis, kreatif, sesuai dengan tujuan dan fungsi PKn (Permendiknas No.22 Tahun 2006).

\section{Keterbatasan Penelitian}

Dalam penelitian ini masih terdapat keterbatasan peneliti. Keterbatasan tersebut yaitu penerapan model active learning tipe role reversal question dalam pelaksanaan pembelajaran $\mathrm{PKn}$ dilakukan secara sederhana belum menggabungkan model active learning tipe lain.

\section{KESIMPULAN DAN SARAN}

\section{a. Kesimpulan}

Berdasarkan hasil penelitian dan pembahasan dapat disimpulkan bahwa pembelajaran PKn mengunakan model active learning tipe role reversal question dapat meningkatkan hasil belajar siswa Kelas X SMA Swasta Melati Binjai. Langkah-langkah model active learning tipe role reversal question meliputi; guru membuat pertanyaan sesuai materi sebelum kegiatan pembelajaran dimulai, menjelaskan kegiatan pembelajaran, membagi siswa dalam beberapa kelompok, menugaskan siswa untuk melakukan diskusi kelompok, menugaskan siswa membuat pertanyaan individu, melakukan tanya jawab dengan bertukar peran dan memberikan umpan balik atas jawaban siswa.

Hal ini ditunjukkan dengan siswa yang memperoleh nilai $\geq 70$ pada siklus I meningkat sebesar $25 \%$ dari kondisi awal $44 \%$ menjadi $69 \%$. Kemudian siswa yang memperoleh nilai $\geq 70$ pada siklus II mengalami peningkatan $28 \%$ menjadi

97\%. Nilai rata-rata pada siklus I mengalami peningkatan sebesar $8,75 \%$ dari kondisi awal
66,53 menjadi 75,28 pada siklus I kemudian pada siklus II nilai rata- rata mengalami peningkatan lagi

berbeda dan lebih memperhatikan aktivitas siswa saat bertukar peran.

\section{DAFTAR PUSTAKA}

Agus Suprijono, Cooperative Learning: Teori dan Aplikasi PAIKEM. Yogyakarta: Pustaka Pelajar, 2009).

Agus Karoni, Pembelajaran Active Learning Starts With a Question untuk meningkatkan keaktifan bertanya siswa dalam pembelajaran PKn kelas IV MIM Sraten, Sukoharjo Tahun Ajaran 2010/2011. (Skripsi, UIN Sunan Kalijaga: 2011).

Ari Samandi, Pembelajaran tif (Active Learning), (Jakarta: Teaching Improvement Worshop Enginering Education Develompment Project, 2009).

Arikunto, Suharsimi, Metode Penelitian Tindakan Kelas, (Jakarta: Rineka Cipta, 2007).

Baharudin \& Esa Nur Wahyuni. (2009). Teori Belajar dan Pembelajaran. Yogyakarta: Ar-Ruzz Media, 2009), hal. 15-16

Desmita, Psikologi Perekembangan Peserta Didik: Panduan Bagi Orang Tua dan Guru Dalam Memahami Psikologi Anak Usia SMA, SMP, SMA, (Bandung: Remaja RoSMAakarya: 2009).

Diana Mutiah, Psikologi Bermain Anak Usia Dini, (Jakarta: Kencana Prenada, 2010).

Djiwandono, S, Psikologi Pendidikan, (Jakarta: Grasindo Garamedia Widiasarana Indonesia, 2006).

Hamruni, Strategi Pembelajaran. (Yogyakarta: Insan Madani, 2011).

Hamzah B. Uno\& Nurdin Mohamad, Belajar dengan

Pendekatan 
PAILKEM:Pembelajaran Aktif, Inovatif, Lingkungan, Kreatif, Efektif, Menarik, (Jakarta: Bumi Aksara, 2012).

Hiszyam Zaini. (2008). Strategi Pembelajaran Aktif. Binjai: Insan Madani, 2008).

Moh. Sholeh Hamid, Metode Edutaiment, Yogyakarta: Diva Press. Redja, 2011). 